DOI: https://doi.org/10.29038/2227-1376-2021-38-110-123

УДК 159.99

\title{
МЕДІАРЕЛІГІЙНА АКТИВНІСТЬ ЯК ЧИННИК ПСИХОЛОГІЧНОГО БЛАГОПОЛУЧЧЯ ОСОБИСТОСТІ
}

\author{
Коструба Наталія \\ Волинський національний університет імені Лесі Українки, \\ м. Луцьк, Україна, \\ nataliia.kostruba@vnu.edu.ua \\ ORCID: https://orcid.org/0000-0002-3852-4729
}

Мета. У статті здійснено емпіричний аналіз психологічного благополуччя особистості у взаємозв'язку з їі медіарелігійною активністю.

Методи. Для реалізації мети дослідження були використані такі методи: стандартизовані опитувальники (Методика внутрішньої стійкості BASIC PH, Опитувальник «Стабільність психічного здоров'я - коротка форма» (MHCSFUA) та опитувальник часової перспективи Ф. Зімбардо (україномовна адаптація О. Сеник)), а також метод наративу. Серед статистичних методів було застосовано кореляційний аналіз Пірсона та знаходження відмінностей в розподілі оцінок.

Результати. Значна частина респондентів реалізує свою потребу у релігійній приналежності за допомогою медіасередовища $(61,7 \%)$. Медіарелігійна активність статистично значимо прямо пропорційно корелює 3 типом автонаративу, позитивним минулим, стабільністю психічного здоров'я, віруваннями та цінностями. Тобто опитувані, що часто звертаються до інформаційних тематичних джерел та релігійних практик схильні позитивно оцінювати своє минуле, у них високі показники стабільності психічного здоров'я. Виявлено статистично значимі відмінності у показниках психологічного благополуччя опитаних, які $є$ медіарелігійно активними, та тих, хто не використовує релігійні ресурси у медіапросторі. Такі данні свідчать, що медіарелігійно активні особистості осмислюють свій досвід та знаходять у ньому нові смисли, частіше відчувають щастя, можливість зробити важливий внесок для суспільства, цікавість до життя, знаходять опору у вірі та духовних цінностях, які допомагають пережити кризові періоди, а також схильні покладатися на Божественні сили у процесі вирішення проблем.

Висновки. Медіарелігійна активність особистості пов’язана із високими показниками психологічного благополуччя, а саме із стабільністю психічного здоров'я, із віруваннями та цінностями як копінг стратегією подолання стресових життєвих обставин. Перспективою подальших досліджень може служити уточнення взаємозв'язків та відмінностей медіарелігійності

ISSN 2308-3743 (Online), ISSN 2227-1376 (Print)

(C) Коструба Н., 2021. Ця стаття відкритого доступу на умовах CC BY-NC 4.0 
особистості із іншими показниками психологічного благополуччя та психічного здоров'я.

Ключові слова: психічне здоров'я, медіа, релігія, активність, копінг.

\section{Kostruba Natalia. Mediereligious activity as a factor of psychological well- being of personality.}

Purpose. The article provides an empirical analysis of the individual's psychological well-being in relation to its media-religious activity.

Methods. To achieve the purpose of the study the following methods were used: standardized questionnaires (BASIC PH Internal Stability Methodology, Mental Health Stability - Short Form Questionnaire (MHCSF-UA) and F. Zimbardo's Time Perspective Questionnaire (Ukrainian-language adaptation by O. Senyk)), as well as the method of narrative. Pearson's correlation analysis and finding differences in the distribution of estimates among the statistical methods were used.

Results. A significant number of respondents realize their need for religious affiliation through the media (61.7\%). Media religious activity correlates with the type of self-narrative, positive assessment of the past, mental health stability, beliefs and values as a coping resource. That is, respondents who often turn to informational thematic sources and religious practices tend to evaluate their past positively, they have high rates of mental health stability. It has been found statistically significant differences in the indicators of psychological well-being of respondents who are media-religiously active and those who do not use religious resources in the media space. So, individual's media-religious activity comprehend their experiences and find new meanings in them, more often feel happiness, opportunity to make an important contribution to society, interest in life, find support in faith and spiritual values that help to survive crises, and prone to rely on divine forces in the process of solving problems.

Conclusions. Media religious activity is associated with high levels of psychological well-being, namely the stability of mental health, beliefs and values as a coping strategy for overcoming crises. Further research may look to clarify the relationships and differences between a person's media religiosity and other indicators of psychological well-being and mental health.

Keywords: mental health, media, religion, activity, coping.

Коструба Наталья. Медиарелигионная активность как фактор психологического благополучия личности.

Цель. В статье проведен эмпирический анализ психологического благополучия личности во взаимосвязи с ее медиа-религиозной активностью.

Методы. Для реализации цели исследования были использованы методы следующих методов: стандартизированные опросники (MHCSF-UA) и опросник временной перспективы Ф. Зимбардо, а также метод нарратива. Среди статистических методов был применен корреляционный анализ Пирсона и отличие в распределении оценок. 
Результаты. Значительная часть респондентов реализует свою потребность в религиозной принадлежности с помощью медиасреды $(61,7 \%)$. Медиарелигиозная активность статистически значимо прямо пропорционально коррелирует с типом автонаратива, положительным прошлым, стабильностью психического здоровья, верованиями и ценностями. То есть опрашиваемые, часто обращающиеся к информационным тематическим источникам и религиозным практикам, склонны положительно оценивать свое прошлое, у них высокие показатели стабильности психического здоровья. Выявлены статистически значимые различия в показателях психологического благополучия опрошенных, которые являются медиарелигиозно активными, и тех, кто не использует религиозные ресурсы в медиапространстве. Такие данные свидетельствуют, что медиа-религиозно-активные личности осмысливают свой опыт и находят в нем новые смсли, чаще испытывают счастье, возможность внести важный вклад для общества, интерес к жизни, находят опору в вере и духовных ценностях, которые помогают пережить кризисные периоды полагаться на Божественные силы. в процессе разрешения проблем.

Выводы. Медиарелигиозная активность личности связана с высокими показателями психологического благополучия, а именно со стабильностью психического здоровья, с верованиями и ценностями как копинг стратегией преодоления стрессовых жизненных обстоятельств. Перспективой дальнейших исследований может быть уточнение взаимосвязей и различий медиарелигиозности личности с другими показателями психологического благополучия и психического здоровья.

Ключевые слова: психическое здоровье, медиа, религия, активность, копинг.

Вступ. Період пандемії та соціальні обмеження значно вплинули на активність особистості. Все більше сфер життєдіяльності трансформуються у онлайн-сервіси. Уже не потрібно покидати домівку, щоб поїсти їжу з ресторану, зробити покупки, відвідати психотерапевта чи долучитися до релігійних обрядів. Усі ці види активності особистість може здійснити онлайн за допомогою мережі інтернет.

В період трансформацій велика увага приділяється питанню психологічного благополуччя, адже адаптація до змін складний процес. Період пандемії, який посилює тривогу за здоров'я та соціальні обмеження значно впливають на психологічне благополуччя молоді, про що свідчать результати попередніх наших досліджень (Kostruba, 2021). Церкви служать джерелом зв'язку та підтримки духовного благополуччя. Зовсім недавно церковні громади 
визнали важливість розширення підтримки за межі духовності та застосування цілісного підходу, який включає психічне та фізичне здоров'я. Те, як кожна церква надає підтримку, залежить від конфесій та потреб їхніх громад (Williams, 2021). У цьому дослідженні ми зосередили увагу на медіарелігійній активності, яка може бути тим психологічним ресурсом та способом подолання негативних стресових ситуацій для підтримки психологічного благополуччя особистості.

Аналізуючи діяльність релігійних організацій у пандемію вчені стверджують, що таким організаціям довелося або припинити свою діяльність, або залишити членів Церкви організовувати свою релігійну практику на індивідуальній або домашній основі або продовжувати свою звичну обрядовість в онлайн-форматі, покладаючись на мотивацію та технічні навички своїх учасників. Т. Vekemans досліджує онлайн-дискурси, які розкривають соціальний i психічний вплив пандемії на релігійну спільноту, а також особливості переміщення діяльності церков в цифрову сферу. Так, цей вчений $є$ одним із амбасадорів дискусії про довгострокові наслідки цього спричиненого кризою цифрового повороту в релігійній практиці, і в соціокультурному житті загалом (Vekemans, 2021).

Дискусії про медіарелігію та медіарелігійну активність розпочинаються на методологічному рівні. Сьогодні важко розділити онлайн- та офлайн-простір і види діяльності, і це також стосується цифрової релігії, оскільки релігійні простори онлайн та офлайн стають змішаними або розмитими. Так, польський дослідник P. Siuda пропонує концептуальну основу для відображення цифрової релігії. Чотири види того, що є релігійним в Інтернеті представлені на основі впливової класифікації Хелланда (Helland, 2005). Він розділяє релігію онлайн (сайти, які надають інформацію без інтерактивності) та онлайн-релігію (інтерактивність і участь), крім того автор додає два типи: інноваційну релігію (нові релігійні течії, культи тощо) та традиційну релігію (наприклад, християнство чи іслам). На основі цих видів P. Siuda пропонує свою модель як спосіб картографування цифрової релігії (Siuda, 2021).

Вплив COVID-19 на психічне здоров'я населення в цілому та існуючі механізми подолання, щоб адаптуватися до нової реальності вивчала на основі глибоких інтерв'ю група пакістанських вчених (Ali et al., 2021). Загалом, результати дослідження підтверджують, що 
соціальні, фінансові та релігійні наслідки пандемії спричинили підвищену тривожність і страх, а також психологічний стрес для членів громади. Респонденти розповідали про такі механізми подолання, як наближення до Бога, зв'язок з сім'єю, участь у подіях спрямованих на підтримку психічного здоров'я та відновлення життя. Щодо релігійної активності, то через заборону масових молитов i зібрань, що було джерелом внутрішнього задоволення для багатьох, люди почуваються некомфортно і невпевнено. Для подолання цих негативних емоційних станів респонденти посили свою індивідуальну молитву і «у ці складні часи наблизилися до Бога». Також кілька опитаних стверджували, що релігія та віра додає їм сили та надії впоратися з поточною стресовою ситуацією (Ali et al., 2021).

Пандемія також призвела до позитивного відновлення взаємодії 3 релігією та духовністю, оскільки заходи карантину здійснили цифровий поштовх із переходом діяльності на онлайн-платформи. Були започатковані релігійні та духовні ініціативи онлайн та офлайн, щоб сприяти добробуту та служити тим, хто найбільше цього потребує. Про такий вплив стверджує група австралійських вчених, які здійснили грунтовний аналіз репрезентацій у ЗМІ релігійних, духовних та нерелігійних реакцій на COVID-19 пандемія в Мельбурні (Halafoff, et al., 2021).

Релігійність людей є причиною зміцнення їхнього соціального здоров'я шляхом підвищення солідарності між громадою та запобігання так званої «психічної ерозії» шляхом зміцнення членства індивідів у групах, підвищення їх здібностей та покращення їхньої соціальної ефективності у виконанні своїх завдань та вирішенні соціальних проблем (Tajbakhsh, 2021).

Психологічне благополуччя $\epsilon$ основною ознакою психічного здоров'я, i його можна визначити як гедонічне (насолода, задоволення) та евдемонічне (сенс, виконання) щастя, а також стійкість (впоратися, регулювати емоції, здорове вирішення проблем) (Tang, Tang, Gross, 2019). Деякі американські вчені вважають, що психологічне благополуччя пов'язане 3 гнучким i творчим мисленням, просоціальною поведінкою та хорошим фізичним здоров'ям (Huppert, 2009).

Ми у дослідження розглядаємо психологічне благополуччя грунтуючись на структурному підході, одним із основоположників у 
психології є Л.С. Виготський (Выготский, 1982), у межах якого класичними є компоненти: поведінковий, емоційно-мотиваційний i когнітивний. Такий підхід перекликається із концепцією Y-Y Tang, R. Tang та J.J. Gross (Tang, Tang, Gross, 2019). Так, емоційний компонент психологічного благополуччя ми розглядаємо як задоволення від життя, когнітивний - як знаходження сенсу i осмислення свого життя і досвіду, поведінковий - як володіння конструктивними копінг механізмати та внутрішньою стійкістю у стресових ситуаціях. Власне згідно нашої гіпотези, саме медіарелігійна активність може виступати копінг стратегією для подолання негативних психологічних наслідків пандемії.

Отже, метою статті - емпіричне вивчення взаємозв'язку медіарелігійної активності та психологічного благополуччя особистості.

Методи та процедура дослідження. Для реалізації мети дослідження були використані методи такі методи: стандартизовані опитувальники (Методика внутрішньої стійкості BASIC PH, Опитувальник «Стабільність психічного здоров'я - коротка форма» (MHCSF-UA) (Носенко, Четверик-Бурчак, 2014) та опитувальник часової перспективи Ф. Зімбардо (україномовна адаптація О. Сеник)) (Сеник та ін., 2017), а також метод наративу. Серед статистичних методів було застосовано кореляційний аналіз Пірсона та знаходження відмінностей в розподілі оцінок $\left(\chi^{2}\right)$.

Опис досвіду особистості у вигляді наративу часто використовується у дослідженнях психологів (Hiles, Cermák, 2008; Murray, Ziegler, 2015). Аналіз наративів здійснювавася 3 використанням типології наративів: амбівалентний, емоційнопозитивний, емоційно нейтральний та емоційно-негативний (Чепелева, 2009).

Вибірку дослідження склали 167 респондентів, середній вік 21,09 років $(\mathrm{SD}=4,52), 3$ них 46 опитаних чоловічої та 121 жіночої статі. Дослідження проводилося онлайн у 2020 році, під час другої хвилі локдауну(жорстких обмежень), i вибірка формувалась із добровольців. Одним із завдань онлайн опитування було «Як змінилось Ваше життя під час пандемії Covid-19. Будь ласка, опишіть свій досвід розгорнуто». Матеріалом для дослідження слугували отримані наративи. Крім того, досліджувані відповідали на запитання: «Чи вважаєте Ви себе релігійною людиною?», «Чи 
відвідували Ви релігійні служби чи церкву протягом останніх пів року?» Ці два питання передбачали відповідь так чи ні. Також респондентам пропонувалось відповісти на запитання «Чи переглядали Ви за останні пів року?» через вибір медіарелігійних активностей, серед яких потрібно було обрати один або декілька варіантів, а саме: трансляції релігійних служб, проповідей; відвідували релігійні сайти; читали новини на релігійну тему; релігійні онлайн сервіси; читали газету чи журнал 3 релігійним контентом; нічого з перерахованого.

Обговорення результатів. Аналіз отриманих результатів ми розпочали із виявлення кількості респондентів, що вважають себе релігійними, здійснюють традиційну та медіарелігійну активність. Результати продемонстровано на рисунку 1.

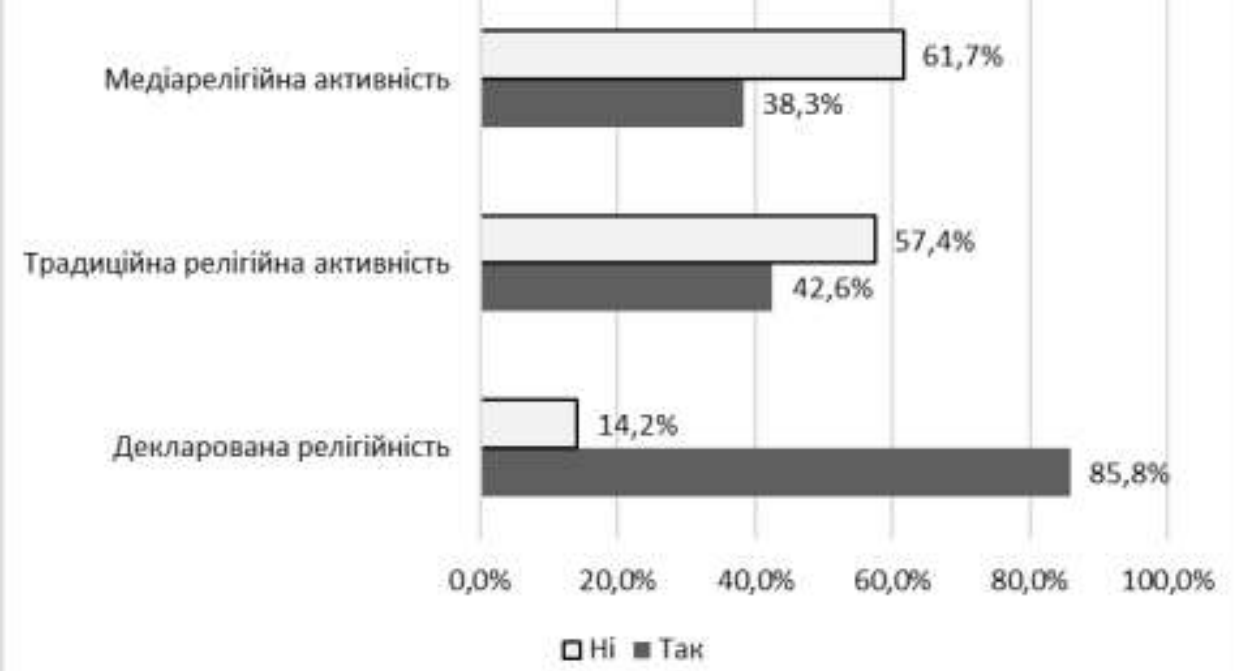

\section{Рис.1. Результати опитування респондентів щодо релігійної активності за останні декілька місяців, \%}

Загалом, серед усіх опитаних релігійними себе вважають 85,8\% i лише $14,2 \%$ описали себе як нерелігійну особистість. 57,4\% респондентів здійснювали у місяці соціальних обмежень через пандемію традиційну релігійну активність, а саме відвідували церкву, тоді як 42,6\% відмовились від такої активності. Хоча б одні із запропонованих медіарелігійних активностей виконувало $61,7 \%$ опитаних, тоді як інші 38,3\%таких дій не робили. Отже, значна частина респондентів реалізує свою потребу у релігійній приналежності за допомогою медіасередовища.

Для виявлення статистично значимих взаємозв'язків психологічного благополуччя з традиційною та медійною релігійною 
активністю ми вирахували коефіцієнт кореляції Пірсона (Табл.1).

Таблиця 1

Статистично значущі коефіціснти кореляції між компонентами психологічного благополуччя та типами релігійної активності

\begin{tabular}{|c|c|c|c|c|}
\hline Методика & Шкали & $\begin{array}{l}\text { Декларована } \\
\text { релігійність }\end{array}$ & $\begin{array}{l}\text { Традиційна } \\
\text { релігійна } \\
\text { активність }\end{array}$ & $\begin{array}{l}\text { Медіарелігійна } \\
\text { активність }\end{array}$ \\
\hline 疍 & Вид автонаратива & $0,262 * *$ & $0,221 * *$ & $0,410 * *$ \\
\hline \multirow{5}{*}{ 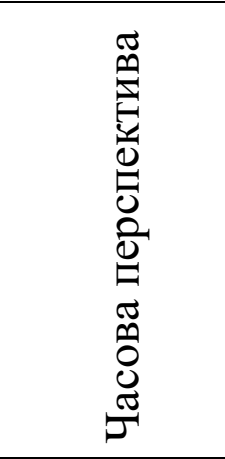 } & Негативне минуле & $0,160 *$ & $0,183^{*}$ & $-0,012$ \\
\hline & $\begin{array}{l}\text { Гедеоністичне } \\
\text { теперішнє }\end{array}$ & $0,309 * *$ & $0,204 *$ & $-0,009$ \\
\hline & $\begin{array}{l}\text { Орієнтація } \\
\text { майбутнє }\end{array}$ & $0,200 *$ & 0,076 & 0,102 \\
\hline & Позитивне минуле & $0,473 * *$ & $0,366 * *$ & $0,160 *$ \\
\hline & $\begin{array}{l}\text { Фаталістичне } \\
\text { теперішнє }\end{array}$ & $0,274 * *$ & $0,217 * *$ & 0,009 \\
\hline 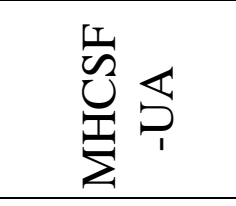 & $\begin{array}{l}\text { Стабільність } \\
\text { психічного } \\
\text { здоров'я }\end{array}$ & 0,084 & 0,054 & $0,171 *$ \\
\hline \multirow{6}{*}{ 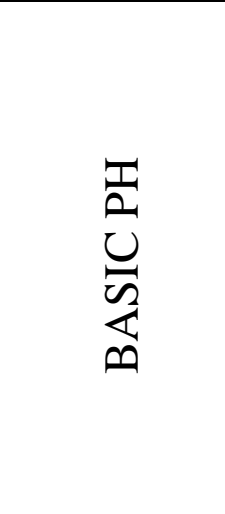 } & $\begin{array}{l}\text { Вірування } \\
\text { цінності }\end{array}$ & $0,339 * *$ & $0,289 * *$ & $0,314 * *$ \\
\hline & Почуття & $0,190 *$ & 0,087 & 0,001 \\
\hline & $\begin{array}{l}\text { Соціальна } \\
\text { приналежність }\end{array}$ & $0,169 *$ & 0,127 & 0,122 \\
\hline & Уява & 0,126 & 0,084 & 0,066 \\
\hline & Мислення & 0,032 & $-0,061$ & 0,053 \\
\hline & $\begin{array}{l}\text { Фізична } \\
\text { модальність }\end{array}$ & 0,082 & 0,051 & 0,131 \\
\hline
\end{tabular}

Примітка: *-статистично значущий зв'язок на рівні 0,05 ; ** - статистично значущий зв'язок на рівні 0,01 .

Виявлено статистично значимий прямо пропорційний взаємозв’язок декларованої релігійності із типом автонаративу ( $\mathrm{r}=0,262 ; \mathrm{p}<0,01)$, а також зі шкалами негативне минуле ( $\mathrm{r}=0,160$; $\mathrm{p}<0,05)$, гедеоністичне теперішне $(\mathrm{r}=0,309 ; \mathrm{p}<0,01)$, орієнтація на майбутнє ( $\mathrm{r}=0,200 ; \mathrm{p}<0,05)$, позитивне минуле $(\mathrm{r}=0,473 ; \mathrm{p}<0,01)$, фаталістичне теперішне $(\mathrm{r}=0,274 ; \mathrm{p}<0,01)$, вірування та цінності ( $\mathrm{r}=$ $0,339 ; \mathrm{p}<0,01)$, почуття ( $\mathrm{r}=0,190 ; \mathrm{p}<0,05)$ та соціальна приналежність $(\mathrm{r}=0,169 ; \mathrm{p}<0,05)$. Таким чином, опитані iз декларованою 
релігійністю часто описували свій досвід емоційно-позитивно та при подоланні важких стресових ситуацій часто опираються на свої вірування та цінності, почуття та соціальну приналежність.

Прямо пропорційно статистично значимо традиційна релігійна активність пов' язана із типом автонаративу $(\mathrm{r}=0,221 ; \mathrm{p}<0,01)$, а також зі шкалами негативне минуле $(\mathrm{r}=0,183 ; \mathrm{p}<0,05)$, гедеоністичне теперішнє ( $\mathrm{r}=0,204 ; \mathrm{p}<0,05)$, позитивне минуле $(\mathrm{r}=0,366 ; \mathrm{p}<0,01)$, фаталістичне теперішне $(\mathrm{r}=0,217 ; \mathrm{p}<0,01)$, вірування та цінності $(\mathrm{r}=0,289 ; \mathrm{p}<0,01)$. Так, люди, які відвідують церкву частіше описують свій досвід як позитивний та схильні використовувати свої вірування та цінності як копінг-стратегію.

Медіарелігійна активність статистично значимо прямо пропорційно корелює 3 типом автонаративу ( $\mathrm{r}=0,410 ; \mathrm{p}<0,01)$, позитивним минулим ( $\mathrm{r}=0,160 ; \mathrm{p}<0,05)$, стабільністю психічного здоров'я $(\mathrm{r}=0,71 ; \mathrm{p}<0,05)$, віруваннями та цінностями $(\mathrm{r}=0,314$; $\mathrm{p}<0,01)$. Тобто опитувані, що часто звертаються до інформаційних тематичних джерел та релігійних практик схильні позитивно оцінювати своє минуле, у них високі показники стабільності психічного здоров'я. Респонденти, які не схильні до медіарелігійної активності частіше описують своє життя емоційно-негативно та демонструють стан пригнічення та відсутність симптомів гедонічного благополуччя. Також виявлена кореляція демонструє, що медіарелігійна активність взаємопов'язана із віруваннями та цінностями як копінг стратегією подолання стресових життєвих обставин. Так, ми можемо припустити, що сама медіарелігійна активність може виступати чинником психологічного благополуччя особистості.

Для подальшого уточнення отриманих даних ми застосували знаходження відмінностей в розподілі оцінок $\left(\chi^{2}\right)$. У таблиці 2 наведено лише статистично значимі показники відмінностей $\mathrm{y}$ показниках (складових) психологічного благополуччя опитаних, які $€$ медіарелігійно активними, та тих, хто не використовує релігійні ресурси у медіапросторі.

За результатами статистичного порівняння було виявлено значимі відмінності у показниках оцінки досвіду респондентами у наративах $\left(\chi^{2}=303,1 ; p<0,001\right)$. Такі данні свідчать, що медіарелігійно активні особистості схильні описувати свій досвід емоційнопозитивно, осмислювати його, надавати йому нових сенсів, вони 
приймають і описують свою історію та життєві зміни. Тоді як опитані, які не схильні до медіарелігійної активності частіше описують свій досвід негативно, неприймаючи його, витісняючи свої проблеми.

Таблиия 2

\section{Статистично значущі відмінності в розподілі показників психологічного благополуччя медіарелігійно активних/ неактивних респондентів}

\begin{tabular}{|c|c|}
\hline & $\begin{array}{l}\text { Медіарелігійна } \\
\text { активність }\end{array}$ \\
\hline Вид автонаратива & $303,133 * * *$ \\
\hline $\begin{array}{l}\text { Стабільність } \\
\text { психічного здоровя }\end{array}$ & $319,140 * * *$ \\
\hline Вірування та цінності & $175,503 * *$ \\
\hline Уява & $169,904 * *$ \\
\hline
\end{tabular}
значущий відмінності на рівні 0,$01 ; * * *$ - статистично значущі відмінності на рівні 0,001 .

Виявлено відмінності у стабільності психічного здоров'я медіарелігійно активних/ неактивних респондентів $\left(\chi^{2}=319,1\right.$; $\mathrm{p}<0,001)$. Так, особистості медіарелігійно активні характеризуються психологічним благополуччям, стійкістю психічного здоров'я, що проявляється у відчутті щастя, що є можливість зробити важливий внесок для суспільства, цікавості та задоволенні від життя. Натомість респонденти, що не практикують медіарелігійну активність демонструють низький рівень стабільності психічного здоров'я, психологічного та соціального благополуччя, відчувають пригнічення.

Значимі відмінності у досліджуваних групах виявлені у показниках вірувань та цінностей як копінг-механізмів подолання $\left(\chi^{2}=175,5 ; \mathrm{p}<0,01\right)$. Медіарелігійно активні особистості знаходять опору у вірі та духовних цінностях, які допомагають пережити важкі часи стресу та змін. Респонденти, які не реалізуть медіарелігійну активність не схильні у стресових ситуаціях використовувати віру та цінності як копінг-мехінізм.

Статистично значимі відмінності виявлені у розподілі оцінок за шкалою уява як спосіб подолання кризових життєвих ситуацій $\left(\chi^{2}=\right.$ $169,9 ; \mathrm{p}<0,05)$. Особи медіарелігійно активні можуть користуватися своєю уявою, щоб відірватися від реальності та іï проблем. Тут 
людина може бачити вирішення проблем через Божественне втручання. Іноді може спостерігатись у крайньому випадку як перенесення відповідальності за власне життя на Божественні сили. Люди, які не практикують медіарелігійну активність не використовують уяву як спосіб подолання складних ситуацій.

Висновки і перспективи. В період пандемії та соціальних обмежень люди перебувають у пошуку ресурсів і методів подолання негативних психологічних наслідків, які виникли через зміну звичного способу життя та страху за своє здоров'я. У нашому дослідженні ми продемонстрували емпіричні докази, що медіарелігійна активність особистості пов'язана із високими показниками психологічного благополуччя, а саме із стабільністю психічного здоров'я, із віруваннями та цінностями як копінг стратегією подолання стресових життєвих обставин. Такі данні підтверджені статистично кореляційним аналізом та знаходженням відмінностей у розподілі оцінок. Таким чином, власне медіарелігійна активність може виступати копінг-стратегію подолання важких життєвих обставин. Загалом, медіарелігійно активні особистості осмислюють свій досвід та знаходять у ньому нові смсли, частіше відчувають щастя, можливість зробити важливий внесок для суспільства, цікавість до життя, знаходять опору у вірі та духовних цінностях, які допомагають пережити кризові періоди, а також схильні покладатися на Божественні сили у процесі вирішення проблем.

Перспективою подальших досліджень може служити уточнення взаємозв'язків та відмінностей медіарелігійності особистості із іншими показниками психологічного благополуччя та психічного здоров'я.

\section{Література} T.1. M.

1. Выготский, Л.С. (1982). Проблема развития в структурной психологии.

2. Носенко, Е. Л., Четверик-Бурчак А. Г. (2014). Опитувальник «Стабільність психічного здоров'я - коротка форма»: опис, адаптація, застосування. Вісник Дніпропетровського університету. Серія "Педагогіка $i$ психологія», 20, 89-97.

3. Сеник, О., Абрамов, В., Ружицька, М., Бабатіна, С., Бедан, В., Бунас, А., Дворник, М., Свченко, І., Клименко, О., Кузьменко, Я., Луценко, О., Мандзик, Т., Охріменко, В., Різник Р. (2017). Опитувальник часової перспективи Ф. Зімбардо: результати валідизації російськомовної версії на 
російськомовних українцях та перегляду ключів української версії. Гуманітарний вісник ДВНЗ “Переяслав-Хмельницький державний педагогічний університет імені Григорія Сковороди”, 37-1, VI (74) : Тематичний випуск "Вища освіта України у контексті інтеграції до Європейського освітнього простору", 428-449.

4. Чепелева, Н.В. (Ред.) (2009). Проблемы психологической герменевтики. К. : Издательство Национального педагогического университета им. Н.П. Драгоманова.

5. Ali, N.A., Feroz, A.S., Akber, N., et al. (2021). When COVID-19 enters in a community setting: an exploratory qualitative study of community perspectives on COVID-19 affecting mental well-being. BMJ Open, 11:e049851. DOI: https://doi.org/10.1136/bmjopen-2021-049851

6. Halafoff, A., Marriott, E., Smith, G., Weng, E., Bouma, G. (2021).Worldviews Complexity in COVID-19 Times: AustralianMedia Representations of Religion, Spirituality and Non-Religion in 2020. Religions, 12, 682. https://doi.org/10.3390/rel12090682

7. Helland, Ch. (2005). Online Religion as Lived Religion. Methodological Issues in the Study of Religious Participation on the Internet. Online-Heidelberg Journal of Religions on the Internet, 01.1. Special Issue on Theory and Methodology. DOI: https://doi.org/10.11588/heidok.00005823

8. Hiles, D. \& Cermák, I. (2008). Narrative psychology. In The SAGE handbook of qualitative research in psychology (pp. 147-164). SAGE Publications Ltd, https://www.doi.org/10.4135/9781848607927

9. Huppert, F. A. (2009). Psychological Well-being: Evidence Regarding its Causes and Consequences. Applied psychology: health and well-being, 1 (2), 137 164. DOI: https://doi.org/10.1111/j.1758-0854.2009.01008.x

10. Kostruba, N. (2021). Social Restrictions in the COVID-19 Pandemic As a Traumatic Experience: Psycholinguistic Markers. East European Journal of Psycholinguistics, 8(1), 28-40. https://doi.org/10.29038/eejpl.2021.8.1.kos

11. Murray, M., \& Ziegler, F. (2015). The narrative psychology of community health workers. Journal of health psychology, 20(3), 338-349. https://doi.org/10.1177/1359105314566615

12. Siuda, P. (2021). Mapping Digital Religion: Exploring the Need for New Typologies. Religions, 12, 373. https://doi.org/10.3390/rel12060373

13. Tajbakhsh, Gh. (2021). COVID-19 and the Lived Experience of People Facing it; a Quantitative Study. Journal of Education and Community Health, 8(2), 127-133. https://doi.org/10.52547/jech.8.2.127

14. Tang, Y-Y, Tang, R. and Gross, J.J. (2019). Promoting Psychological WellBeing Through an Evidence-Based Mindfulness Training Program. Front. Hum. Neurosci, 13, 237. https://doi.org/10.3389/fnhum.2019.00237

15. Vekemans, T. (2021). Crisis and Continuation: The Digital Relocation of Jain Socio-Religious Praxis during the COVID-19 Pandemic. Religions, 12, 342. https://doi.org/10.3390/rel12050342

16. Williams, M. J., Wagoner, Z., Rodman-Alvarez, S., Pasillas, V. \& Sanchez, 
A. (2021) Prioritizing health: Churches response to the COVID-19 pandemic. Journal of Prevention \& Intervention in the Community. https://doi.org/10.1080/10852352.2021.1924593

\section{References}

1. Vyigotskiy, L.S. (1982). Problema razvitiya $v$ strukturnoy psihologii [The problem of development in structural psychology]. T.1. M. [in Russian].

2. Nosenko, E. L., Chetveryk-Burchak, A. H. (2014). Opytuvalnyk «Stabilnist psykhichnoho zdorovia - korotka forma»: opys, adaptatsiia, zastosuvannia [Mental Health Stability - Short Form Questionnaire: description, adaptation, application]. Visnyk Dnipropetrovskoho universytetu. Seriia «Pedahohika i psykholohiia» Bulletin of Dnipropetrovsk University. Series "Pedagogy and Psychology", 20, 89-97 [in Ukrainian].

3. Senyk, O., Abramov, V., Ruzhytska, M., Babatina, S., Bedan, V., Bunas, A., Dvornyk, M., Yevchenko, I., Klymenko, O., Kuzmenko, Ya., Lutsenko, O., Mandzyk, T., Okhrimenko, V., Riznyk R. (2017). Opytuvalnyk chasovoi perspektyvy F. Zimbardo: rezultaty validyzatsii rosiiskomovnoi versii na rosiiskomovnykh ukraintsiakh ta perehliadu kliuchiv ukrainskoi versii [Time perspective questionnaire F. Zimbardo: results of validation of the Russian-language version on Russianspeaking Ukrainians and revision of the keys of the Ukrainian version]. Humanitarnyi visnyk DVNZ "Pereiaslav-Khmelnytskyi derzhavnyi pedahohichnyi universytet imeni Hryhoriia Skovorody" - Humanitarian Bulletin of PereyaslavKhmelnytsky State Pedagogical University named after Hryhoriy Skovoroda, 37-1, VI (74), 428-449 [in Ukrainian].

4. Chepeleva, N.V. (Eds.) (2009). Problemyi psihologicheskoy germenevtiki [Problems of psychological hermeneutics]. K.: Izdatelstvo Natsionalnogo pedagogicheskogo universiteta im. N.P. Dragomanova [in Russian].

5. Ali, N.A., Feroz, A.S., Akber, N., et al. (2021). When COVID-19 enters in a community setting: an exploratory qualitative study of community perspectives on COVID-19 affecting mental well-being. BMJ Open, 11:e049851. DOI: https://doi.org/10.1136/bmjopen-2021-049851

6. Halafoff, A., Marriott, E., Smith, G., Weng, E., Bouma, G. (2021).Worldviews Complexity in COVID-19 Times: AustralianMedia Representations of Religion, Spirituality and Non-Religion in 2020. Religions, 12, 682. https://doi.org/10.3390/rel12090682

7. Helland, Ch. (2005). Online Religion as Lived Religion. Methodological Issues in the Study of Religious Participation on the Internet. Online-Heidelberg Journal of Religions on the Internet, 01.1. Special Issue on Theory and Methodology. DOI: https://doi.org/10.11588/heidok.00005823

8. Hiles, D. \& Cermák, I. (2008). Narrative psychology. In The SAGE handbook of qualitative research in psychology (pp. 147-164). SAGE Publications Ltd, https://www.doi.org/10.4135/9781848607927

9. Huppert, F. A. (2009). Psychological Well-being: Evidence Regarding its 
Causes and Consequences. Applied psychology: health and well-being, 1 (2), $137-$ 164. DOI: https://doi.org/10.1111/j.1758-0854.2009.01008.x

10. Kostruba, N. (2021). Social Restrictions in the COVID-19 Pandemic As a Traumatic Experience: Psycholinguistic Markers. East European Journal of Psycholinguistics, 8(1), 28-40. https://doi.org/10.29038/eejpl.2021.8.1.kos

11. Murray, M., \& Ziegler, F. (2015). The narrative psychology of community health workers. Journal of health psychology, 20(3), 338-349. https://doi.org/10.1177/1359105314566615

12. Siuda, P. (2021). Mapping Digital Religion: Exploring the Need for New Typologies. Religions, 12, 373. https://doi.org/10.3390/rel12060373

13. Tajbakhsh, Gh. (2021). COVID-19 and the Lived Experience of People Facing it; a Quantitative Study. Journal of Education and Community Health, 8(2), 127-133. DOI: https://doi.org/10.52547/jech.8.2.127

14. Tang, Y-Y, Tang, R. and Gross, J.J. (2019). Promoting Psychological WellBeing Through an Evidence-Based Mindfulness Training Program. Front. Hum. Neurosci, 13, 237. DOI: https://doi.org/10.3389/fnhum.2019.00237

15. Vekemans, T. (2021). Crisis and Continuation: The Digital Relocation of Jain Socio-Religious Praxis during the COVID-19 Pandemic. Religions, 12, 342. https://doi.org/10.3390/rel12050342

16. Williams, M. J., Wagoner, Z., Rodman-Alvarez, S., Pasillas, V. \& Sanchez, A. (2021) Prioritizing health: Churches response to the COVID-19 pandemic. Journal of Prevention \& Intervention in the Community. DOI: https://doi.org/10.1080/10852352.2021.1924593

Received: 08.09.2021 Accepted: 04.10.2021 